Article

\title{
Application of the Extended Theory of Planned Behavior Model to Investigate Purchase Intention of Green Products among Thai Consumers
}

\author{
Kamonthip Maichum ${ }^{1}$, Surakiat Parichatnon ${ }^{1}$ and Ke-Chung Peng ${ }^{2, *}$ \\ 1 Department of Tropical Agriculture and International Cooperation, National Pingtung University of Science \\ and Technology, No. 1, Shuefu Road, Neipu, Pingtung 91201, Taiwan; mull_milk@hotmail.com (K.M.); \\ surakiat_parichatnon@hotmail.co.th (S.P.) \\ 2 Department of Agribusiness Management, National Pingtung University of Science and Technology, No. 1, \\ Shuefu Road, Neipu, Pingtung 91201, Taiwan \\ * Correspondence: kchung@mail.npust.edu.tw; Tel.: +886-877-404-29
}

Academic Editors: Sang-Bing Tsai, Bin Liu, Joseph Z. Shyu, Yongjian Li, Yong Deng, Ming-Lang Tseng and Jih-Jeng Huang

Received: 15 June 2016; Accepted: 17 October 2016; Published: 23 October 2016

\begin{abstract}
Green products are among the widely used products worldwide due to their environmental benefits. However, information on the consumers' purchase intention towards green products in developing countries, such as Thailand, is lacking. This study aims to investigate Thai consumers who are aged over 18 years, and whose base education is high school, on purchase intention for green products by using an extended framework of the theory of planned behavior (TPB). We derived and examined the model through structural equation modeling in a sample of 483 respondents in Thailand. The findings of this model indicated that consumer attitude, subjective norm and perceived behavioral control have significant positive influences on the purchase intention for green products. Furthermore, our results indicated that environmental concerns have a significant effect on attitude, perceived behavioral control and purchase intention for green products, but subjective norm. Moreover, environmental knowledge had no significant effect on the purchase intention for green products. Instead, it had a distinct indirect effect through attitude towards purchasing green products, subjective norm and perceived behavioral control. The findings from this study contribute to improving the understanding of intention to purchase green products, which could play a major role towards sustainable consumption.
\end{abstract}

Keywords: environmental concern; environmental knowledge; green products; purchase intention; sustainable consumption; theory of planned behavior

\section{Introduction}

Rapid economic growth has led to adverse environmental degradation. The environment has changed considerably worldwide because of factors such as climate change, air pollution, waste generation and natural disasters, which affect not only living organisms but also the economic and social status of people. Thailand is among the largest economies and business centers in Southeast Asia; industries have developed rapidly, resulting in environmental degradation through over-consumption and over utilization of natural resources. In the wake of such impacts, consumers are concerned about their environment [1]. Among the several ways of reducing their impacts on the environment, they can make appropriate decisions on which goods to purchase. Several studies have suggested that increased awareness and interest in sustainable consumption is expected to influence the purchasing decisions of consumers [2,3]. Furthermore, sustainable consumption has received more attention from corporate decision-makers due to strict environmental regulations and growing pressure of 
stakeholders focused on environmental conservation [2,4-6]. Thus, environmental problems and their adverse impact on human health has become an important issue among academic, government and private organizations $[7,8]$.

The consumption of environmentally friendly products (referred to as green products in this study) could be one way of reducing environmental impacts $[9,10]$. Green products refer to products that are safe to purchase, and are of good quality, and are produced under the principles of sustainable development [11]. In recent years, the production of green products has increased substantially worldwide; products that will not pollute the environment, and can be recycled or conserved using low-toxicity materials [12]. Consequently, they have popularity among consumers globally [2,9].

According to Ottman [13], consumers would purchase green products when their needs or wants for safety, quality, availability and convenience are a priority and when they realize that green products can help to solve environmental problems. Consumers judge the value of a product using quality indicators and then combine this judgment to evaluate their purchase intention. In marketing, most researchers are interested in identifying the source of green products purchase intention [14] as it helps to develop appropriate strategies and in gaining market share for such products. In addition, retaining customers, developing products, and responding to customer needs are the motives of good practices for every business. Several researchers in developed countries have studied the intentions and behavior of consumers towards green products such as in United States [15-17], United Kingdom [18], and Italy [19]. Paul et al. [2] suggested that consumers from developed countries are more concerned about the environment than those from developing countries. Moreover, green products have also drawn the attention of developing countries, including China [20], India [21,22], Indonesia [23], and Malaysia $[17,24]$. In Thailand, research on environmental issues and green purchasing behavior is just getting started when compared to other developing countries [25-27]. A theory widely used to examine the motivation of individuals intention and behavior, is the theory of planned behavior (TPB) $[28,29]$. It is the most popular theoretical framework to explain determinants and antecedents of purchase intention. For this reason, this theoretical framework was adopted in this study.

Previous studies have used the TPB model to examine the motivation of purchase intention for green products without factoring in the impacts of environmental concerns and environmental knowledge. Environmental concerns and environmental knowledge are important factors influencing the buying decision for green products [2,7]. Therefore, products acceptable to customers in terms of cost, quality, performance and product-related environmental concerns should be developed [30,31]. According to Gilg et al. [32], green consumption is a relatively new area of research and more information is still needed on the role of environmental concerns on green consumption. Environmental concern is a direct predictor of specific environmental behavior, which is estimated by the attitude of consumers towards a specific behavior [33,34]. Environmental knowledge on the other hand can provide concepts and general knowledge of how products interact with the natural environment and this could lead to sustainable development. Ohtomo and Hirose [35] observed that if consumers lack knowledge about green products, an attitude-behavior gap result between their environmental concern and their actual purchasing behavior. This may have strong influence on the purchase intention, and could prognosticate sustainable consumption behavior. Thus, environmental concern and environmental knowledge are considered equally important in the purchase decision for green products $[36,37]$. For these reasons, we integrate these two variables (environmental concerns and environmental knowledge) to the TPB model theoretical framework as antecedents of purchase intention for green products.

In addition, previous literature suggests that demographic variables (old age and high level education) influence green products purchasing behavior [2,38-41]. In 2015, Thailand had an estimated population of those aged 18 years (and over) and having a base education of high school of about 35 million people [42], which is half of the entire Thailand population estimated at 70 million. These groups often act as leaders in families having the responsibility to obtain new products, provide information, and to make purchases [43]. This study aims to investigate the intention of sustainable 
consumption through green products by using an extended framework of the TPB model. It will be of great significance especially to policy makers as they develop sustainable marketing strategies specific to the target group.

\section{Theoretical Background and Hypotheses Development}

The structure of the proposed framework is shown in Figure 1. In total, 11 hypotheses are drawn from six constructs, namely, attitude towards purchasing green products, subjective norm, perceived behavioral control, environment concern, environment knowledge and purchase intention for green products.

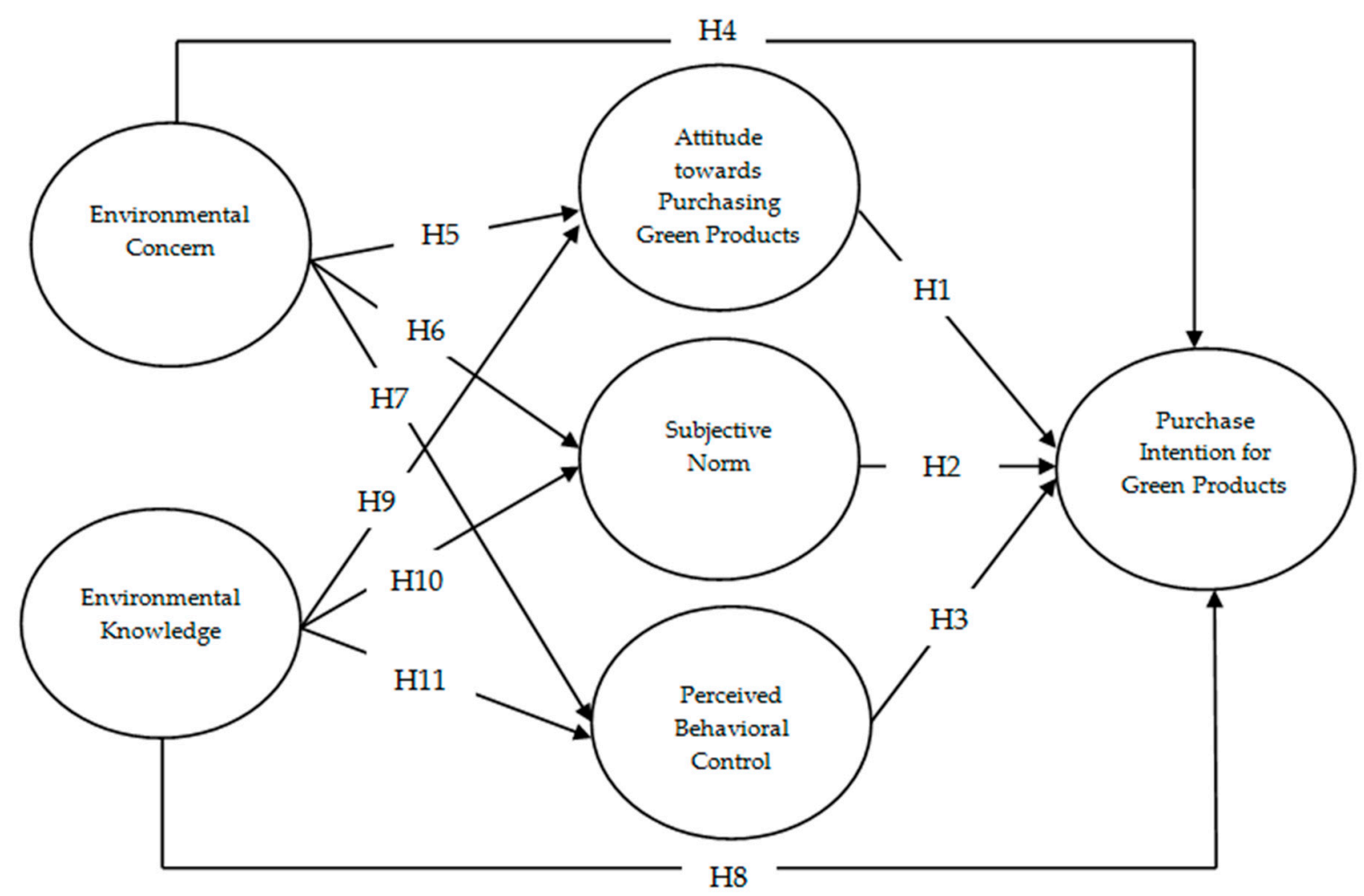

Figure 1. Proposed research framework.

\subsection{Green Products}

Green products have less environmental impact and are less harmful to human health. Srivastava [44] found that green products have evolved as a result of increasing concerns about global warming, global and local pollution levels, diminishing natural reserves, and the overflowing of wastes. Consumers translate environmental concerns into their staunch commitment to purchase green products. Consumers who are aware of and interested about environmental problems are called green consumers [45]. Green or sustainable consumption refers to the widespread change of consumer behavior in order to reduce the environmental impact associated with consumption [46]. According to Roman et al. [47], sustainable consumption implies "the use of goods and services which satisfy the basic needs and enable a better life quality and at the same time the minimization of the consumption of natural resources, the generation of toxic materials and waste and pollutants over a life cycle, so that there is no risk of the impossibility to satisfy the needs of future generations" (p. 2). In the short run, there is a need to create a shared sense of responsibility to the environment that will encourage consumers to buy green products, and in the long run, adopt an environmentally friendly lifestyle [48]. Therefore, the endeavor to understand the intentions of sustainable consumption towards green product is an important part of this study. 


\subsection{The Components of the Extended TPB Model}

TPB has been commended as the best model to predict intentions [7,49]. The TPB framework, an extension of the theory of reasoned action (TRA) [50,51], is one of the most widely researched models among social psychologists for predicting behavioral intentions [52,53]. Intention is a conscious plan of action, which specifically requires a behavior and motivation to actuate it [54]. Many studies describe the intentions and generally think they are the best predictors of behavior and fully mediate the impact of attitudes, subjective norms, and perceived behavioral control $[19,55,56]$. More specifically, intention is accepted as the best available predictor of human behavior, which is at the heart of the TPB framework [55,57]. Rezai et al. [58] applied TPB towards green food consumption in Malaysia, showing that consumers' intention to go green in food consumption is an essential component in the adoption of green products, and Bonini and Oppenheim [1] and Paul et al. [2] demonstrated how this could help achieve environmental sustainability. Jones et al. [59], and Sutton [60] define environmental sustainability as the ability to maintain things or qualities that are of significant value in the physical environment.

\subsubsection{Attitude towards Purchasing Green Products (ATT)}

According to Fazio [61], attitude is an interaction in memory between a given object and a summary evaluation of this object. Attitude is likely to reveal the psychological assessment of a product by the consumer [62-64]. In particular, previous studies have focused on the relationship between attitudes and intention behavior. For example, Irland [65] concluded that consumer's purchasing intentions are dependent upon their environmental attitudes. According to Tsen et al. [66], attitude is among factors that plays a major role in predicting intentions of consumers who will pay for green products. Mostafa [67] found that the positive relationship between attitude and behavioral intention has been established in many cultures. Attitude has a clear role in the decision to accept a specific behavior. Based on literature review, attitude will have an influence towards purchasing green products and as a result, the hypotheses below can be drawn.

H1: Attitude towards purchasing green products is positively associated with purchase intention for green products.

\subsubsection{Subjective Norm (SN)}

Subjective norm refers to the perceived social pressure to perform or not to perform behavior [57,68]. Subjective norm is the opinion of an individual that have an influence in one's decision making [69]. Zukin and Maguire [70] studied social norms and found that they have a major influence on green consumption, and are the basis of many theories and models concerning consumption. Wiriyapinit [71] demonstrated that family norm values imparted by parents in Thailand and purchase intentions were associated. Several studies have reported that the subjective norm is an important determinant of intention to purchase green products [2], organic food [72], and for green hotel revisit intention $[57,73,74]$. Therefore, subjective norm is an important factor in encouraging purchase intention for green products and we propose that:

$\mathrm{H} 2$ : Subjective norm is positively associated with purchase intention for green products.

\subsubsection{Perceived Behavioral Control (PBC)}

Perceived behavioral control refers to an individual's perceived ease or difficulty in performing a particular behavior [68]. A given behavior possibly occurs when an individual has both the ability and motivation to perform that behavior rather than when the individual has only one or neither factors [75]. According to the TPB model, developing perceived behavioral control prior to generating intention is essential. Li et al. [76] proposed that the perceived affordances were perceptual cues that consumers possessed and used to evaluate products before purchasing. Moreover, Olsen [77] pointed 
that the most important control factors that influence consumers food purchasing include self-efficacy, and convenience/availability. Many researchers have concluded that confidence in the ability of the individual to control their behavior showed a positive relationship with purchase intention $[78,79]$. Furthermore, perceived behavioral control has been associated with purchase intention in green hotels [57,73], organic foods [80,81], and green products [82]. Based on this discussion we propose the following hypotheses.

H3: Perceived behavioral control is positively associated with purchase intention for green products.

\subsubsection{Environmental Concern (EC)}

Environmental concern is defined by Alibeli and Johnson [83] as the extent to which people are aware of environmental issues and their willingness to solve environmental problems. Diamantopoulos et al. [37] observed that environmental concerns are an important factor in consumer decision making process. Aman et al. [84] observed that an increasing number of consumers with environmental concerns will increase the intention to purchase green products. Consumers having a higher level of concern towards the environment may result in the purchase of green products. Thus, environmental concern is often cited as a strong motivator to purchase $[85,86]$. Several studies have examined the influence of environmental concern on the green products purchase intention $[84,87,88]$. Irawan and Darmayanti [88] also reported a positive impact of the environmental concern on green purchase intention among university students in Indonesia. Accordingly, the following hypothesis is suggested:

H4: Environmental concern is positively associated with purchase intention for green products.

Environmental concerns are important in the study of environmental attitudes [7,89]. Hanson [89] reported that environmental concern have a positive influence on attitude towards green consumers in Canada. Mostafa [67] observed that environmental concern positively influence the consumers' attitude towards green products which further influences their green purchase intention. Bamberg [90] defines environmental concern as a strong attitude for protecting the environment. Hartmann and Apaolaza-Ibáñez [91] considered the direct and indirect impacts of environmental concern, finding that environmental concern affects attitude and purchase intention towards green products. Thus, we hypothesize that:

H5: Environmental concern is positively associated with attitude towards purchasing green products.

Subjective norm is influenced by the increase in environmental concerns which reduces the perception of difficulty in terms of resources, time, as well as other factors [2]. Therefore, environmental concerns influence behavior through pressure from family and/or friends who accept or reject the green purchase behavior. Bamberg [90] reported that environmental concern has direct effects on subjective norm for students' decision to request an information brochure about green electricity products. This result indicates that the highly environmentally concerned students' perceived a stronger support from important reference persons (such as friends, parents/family, groups from the environmental movement, personally known professors, and energy providers) than low concerned students. Therefore, they showed more interest in obtaining information about green electricity products and intended to use the offered brochure for their actual requirements. Based on this discussion, we propose the following hypotheses.

H6: Environmental concern is positively associated with subjective norm.

In Chen and Tung [73], the intention to visit green hotels was indirectly influenced by environmental concern through attitude, subjective norms, and perceived behavioral control. Bamberg [90] showed that environmental concern can predict perceived behavioral control for energy conservation behaviors. Furthermore, few studies have reported the link between environmental concern and positive influences for attitude, subjective norm and perceived behavioral control [2], 
all of which influences the purchase intention. On the basis of the above discussion, the following hypotheses are proposed.

H7: Environmental concern is positively associated with perceived behavioral control.

\subsubsection{Environmental Knowledge (EK)}

Environmental knowledge is defined by Taufique et al. [92], and Fryxell and Lo [93] as knowledge of the facts, key relationships that lead to environmental impacts, and environmental responsibility of the individual that leads to sustainable development. Hill and Lynchehaun [94] concluded that knowledge of an individual about the environment has a major influence on environmental issues. With an increase in environmental knowledge, the consumers become more informed, and that raises the possibility of high purchase intention [95,96]. Previous studies found that environmental knowledge is one of the important variables that have significant positive influence on consumers' intention to purchase green products [97-99]. As a result, we hypothesize that:

H8: Environmental knowledge is positively associated with purchase intention for green products.

If consumers have the knowledge of environmental issues, it will encourage consumers to have a positive attitude towards green products [84]. Bradley et al. [100] suggested that students have the low knowledge scores had unfavorable environmental attitudes compared with students have the high knowledge scores. Mostafa [67] showed that environmental knowledge is positively linked with attitude towards green products which further influences their purchase intention. Hence, based on the above discussion, this study hypothesizes that:

H9: Environmental knowledge is positively associated with attitude towards purchasing green products.

Moorman et al. [101] suggested that subjective knowledge influences the choice of the consumer, as they are inspired to act on the knowledge they have. Yang and Kahlor [102] proposed that when people perceive that others expect them to know about environmental issues, they might purposely present themselves as knowing a lot about this issue. Thus, people who act according to social norms might have paid more attention to environmental information and actually developed a greater knowledge base. The above discussion leads to the following hypotheses:

H10: Environmental knowledge is positively associated with subjective norm.

According to Kim et al. [103], knowledge will also increase the belief that one has control of the situation, thereby increasing perceived behavioral control. Therefore, it is hypothesized that:

H11: Environmental knowledge is positively associated with perceived behavioral control.

\section{Methodology}

\subsection{Sample and Data Collection}

Data used in this study were obtained from structured questionnaires designed to target those who were 18 years (or older) and highly educated with at least high school education. According to Chan [104], the green context under investigation is very difficult to be understood by minors due to the complexity of thought it brings to decision making. Thus, the ideal sample for this study consisted of adults (age 18 years or older). Furthermore, many researchers have suggested that people with less education find it hard to understand the topic under consideration compared to those with higher education $[2,57,105-107]$. Therefore, quota sampling technique was used in this study to select respondents of or over 18 years of age and having a minimum education level of high school that resided in Thailand. The Thailand National Statistical Office showed that in 2015, Thailand had about 20.601 million households with an average household size of 3.2 people per household. People who are aged 18 years or more and having a minimum high school education for this study had about 
10.938 million households. Moreover, the statistical office showed that households nationwide earned an average of 26,915 THB per month and average income per person was 9212 THB per month [42].

Prior to formal data collection, two pilot tests were conducted. The first pilot test examined the validity and reliability of the questionnaire by testing it on 55 consumers who purchased green products. The comments and suggestions from these respondents were used to improve the questionnaire in terms of simplicity and ease of understanding. After the first revision, a second pilot test was conducted on another 55 consumers to re-evaluate the reliability. Finally, the questionnaire for data collection was established.

Responses were collected through face to face interviews from the consumers. Face to face interview survey was selected as an instrument, because they are based on personal interaction and can be controlled within the survey environment [108], and they reduce the non-response rate [109]. Nunnally and Bernstein [110] recommend a sample size of 300 or more and Charter [111] concluded that a minimum sample size of 400 was needed for a sufficiently precise estimate of the Cronbach's $\alpha$ coefficient. In this study, a total of 550 questionnaires were distributed among consumers (green shops, green market, and convenience and department stores) who bought green products in Thailand from December 2015 to February 2016. In total, 483 usable responses were obtained yielding a response rate of $87.82 \%$, which was much higher than the recommended value of at least 400 for structural equation modeling (SEM). In addition, the sample size was determined based on a confidence level of $95 \%$, with a $5 \%$ margin of error. The questionnaire developed could be completed in approximately 10-15 min. As an incentive to participants, each respondent who completed the questionnaire received 3 USD (approximately $100 \mathrm{THB}$ ) cash as an appreciation for their participation. All questionnaires were returned to the researchers directly after completion without using any intermediaries.

From the descriptive statistics shown in Table 1, a majority of the respondents were females (59.01\%), aged $25-34$ years (42.03\%), married (58.39\%), bachelor's degree $(44.10 \%)$, with a family size of $2-3$ persons (58.18\%), full-time job (32.71\%), and a monthly income range of 30,001-40,000 THB per person $(1 \mathrm{USD}=35.7933 \mathrm{THB}$ as of 1 December 2015).

Table 1. Sample characteristics $(n=483)$.

\begin{tabular}{cccc}
\hline Items & Classification & Frequency & Percentage \\
\hline \multirow{2}{*}{ Gender } & Male & 198 & 40.99 \\
& Female & 285 & 59.01 \\
\hline \multirow{3}{*}{ Age } & $18-24$ years & 79 & 16.36 \\
& $25-34$ years & 203 & 42.03 \\
& $35-44$ years & 132 & 27.33 \\
& $45-54$ years & 46 & 9.52 \\
& 55-64 years & 19 & 3.93 \\
Marital Status & 65 years or older & 4 & 0.83 \\
& Single & 187 & 38.72 \\
& Married & 282 & 58.39 \\
& Divorced/Widowed & 14 & 2.90 \\
\hline \multirow{3}{*}{ Education } & High school & 47 & 9.73 \\
& Diploma & 68 & 14.08 \\
& Bachelor's degree & 213 & 44.10 \\
& Master's degree & 134 & 27.74 \\
& Doctoral degree & 21 & 4.35 \\
\hline \multirow{2}{*}{ Family size } & 1 person & 15 & 3.11 \\
& 2-3 persons & 281 & 58.18 \\
& 4-5 persons & 165 & 34.16 \\
& More than 5 persons & 22 & 4.55 \\
\hline \multirow{2}{*}{ Employment status } & Student & 59 & 12.22 \\
& Housewife & 81 & 16.77 \\
& Unemployed & 47 & 9.73 \\
& Business & 120 & 24.84 \\
& Full-time job & 158 & 32.71 \\
& Part-time job & 18 & 3.73 \\
\hline & & &
\end{tabular}


Table 1. Cont.

\begin{tabular}{cccc}
\hline Items & Classification & Frequency & Percentage \\
\hline & Less than 10,000 & 43 & 8.90 \\
& $10,001-20,000$ & 66 & 13.66 \\
Personal income-monthly (THB) & $20,001-30,000$ & 135 & 27.95 \\
& $30,001-40,000$ & 169 & 34.99 \\
& $40,001-50,000$ & 31 & 6.42 \\
& More than 50,001 & 39 & 8.07 \\
\hline
\end{tabular}

\subsection{Measures}

Measurement variables (shown in Table 2) considered for each construct used in this study were either selected or modified from previous studies. A total of six constructs were used. First, attitude towards green products was measured on three items and extracted from previous studies $[2,99,112]$. Second, the validated three items were used to measure subjective norm taken from these studies $[48,55,72]$. Third, perceived behavioral control was measured on four items based on $[48,72,113]$. Fourth, environmental concern was measured by four different items, as proposed by $[2,21,114]$. Fifth, environmental knowledge was measured using three items based on $[7,21,55]$. Finally, purchase intention for environmentally sustainable products was measured through three items taken from $[2,99,115]$. The questionnaire used the 5-point Likert scale ranging from 1 (strongly disagree) to 5 (strongly agree). This scale asks respondents to indicate how much they strongly disagree or agree with a series of statements on a particular topic [116].

Descriptive statistics of the questionnaire items are provided in Table 2, including the mean values of attitude, subjective norm, perceived behavioral control, environmental concern, environmental knowledge and purchase intention for green products were quite high and relatively favorable. The mean values of subjective norm were low compared with the other constructs at 3.424 because green products are still not common in Thailand.

Table 2. Descriptive statistics of the questionnaire items.

\begin{tabular}{|c|c|c|}
\hline Constructs/Questionnaire Items & Mean & Standard Deviation \\
\hline Attitude towards purchasing green products & 4.102 & 0.847 \\
\hline ATT1: I think that purchasing green product is favorable & 4.081 & 0.728 \\
\hline ATT2: I think that purchasing green product is a good idea & 4.264 & 0.771 \\
\hline ATT3: I think that purchasing green product is safe & 3.962 & 0.638 \\
\hline \multirow{2}{*}{$\begin{array}{l}\text { Subjective norm } \\
\text { SN1: My family think that I should purchase green products rather than } \\
\text { normal products }\end{array}$} & 3.424 & 0.991 \\
\hline & 3.372 & 0.943 \\
\hline $\begin{array}{l}\text { SN2: My close friends think that I should purchase green products rather } \\
\text { than normal products }\end{array}$ & 3.468 & 0.991 \\
\hline $\begin{array}{l}\text { SN3: Most people who are important to me think I should purchase } \\
\text { green products rather than normal products }\end{array}$ & 3.433 & 0.978 \\
\hline \multirow{2}{*}{$\begin{array}{l}\text { Perceived behavioral control } \\
\text { PBC1: I am confident that I can purchase green products rather than normal } \\
\text { products when I want }\end{array}$} & 4.004 & 0.843 \\
\hline & 3.560 & 0.974 \\
\hline \multirow{3}{*}{$\begin{array}{l}\text { PBC2: I see myself as capable of purchasing green products in future } \\
\text { PBC3: I have resources, time and willingness to purchase green products } \\
\text { PBC4: There are likely to be plenty of opportunities for me to purchase } \\
\text { green products }\end{array}$} & 4.218 & 0.742 \\
\hline & 4.342 & 0.737 \\
\hline & 3.894 & 0.851 \\
\hline Environmental concern & 4.125 & 0.773 \\
\hline EC1: I am very concerned about the state of the world's environment & 4.314 & 0.731 \\
\hline EC2: I am willing to reduce my consumption to help protect the environment & 4.481 & 0.876 \\
\hline
\end{tabular}


Table 2. Cont.

\begin{tabular}{lcc}
\hline Constructs/Questionnaire Items & Mean & Standard Deviation \\
\hline EC3: Major social changes are necessary to protect the natural environment & 3.860 & 0.832 \\
EC4: Major political change is necessary to protect the natural environment & 3.843 & 0.893 \\
\hline $\begin{array}{l}\text { Environmental knowledge } \\
\text { EK1: I prefer to check the eco-labels and certifications on green products } \\
\text { before purchase }\end{array}$ & 3.789 & 0.835 \\
$\begin{array}{l}\text { EK2: I want to have a deeper insight of the inputs, processes and impacts of } \\
\text { products before purchase }\end{array}$ & 3.874 & 0.814 \\
$\begin{array}{l}\text { EK3: I would prefer to gain substantial information on green products } \\
\quad \text { before purchase }\end{array}$ & 3.935 & 0.762 \\
\hline $\begin{array}{l}\text { Purchase intention for green products } \\
\text { PI1: I intend to purchase green products next time because of its positive }\end{array} \quad 3.130$ & 0.978 \\
$\quad$ environmental contribution & 3.893 & 0.764 \\
PI2: I plan to purchase more green products rather than normal products & 4.097 & 0.852 \\
\hline PI3: I will consider switching to eco-friendly brands for ecological reasons & 4.399 & 0.813 \\
\hline
\end{tabular}

\subsection{Tools for Analysis}

Data analyses were conducted using the statistical package for social sciences (SPSS 23.0) and analysis of moment structures (AMOS 19.0) software, to achieve the purpose and to test hypotheses of this study. SPSS 23.0 was used for descriptive analysis to analyze preliminary results and to find out the demographic characteristics of the sample. Cronbach's $\alpha$ coefficient was adopted to test the reliability of the measurement items. With AMOS 19.0, confirmatory factor analysis (CFA) was used to assess the adequacy of measurement for confirming the reliability, convergent and divergent validity, followed by using SEM to test the hypothesized relationships among study constructs.

\section{Results}

\subsection{Testing of Reliability and Validity of the Measurement Model}

The measurement model fit was assessed through confirmatory factor analysis (CFA) to confirm the factor loadings of the six constructs; attitude, subjective norm, perceived behavioral control, environmental concern, environmental knowledge and purchase intention for green products. Convergent and discriminant validities and the overall fit with data were examined to ensure the model validity and reliability. To test the internal consistency of the indicators of each studied construct, the most common method is to calculate the coefficient alpha of a given construct [117,118]. As shown in Table 3, Cronbach's $\alpha$ coefficients were calculated for internal validity, and the values ranged from 0.808 to 0.943 . Nunnally and Bernstein [110] suggested Cronbach's $\alpha$ level beyond 0.700 . Therefore, the values obtained suggest that all constructs were internally consistent and reliable.

According to Hair et al. [119], the factor loading should be greater than 0.700 . Therefore, all of standardized factor loadings were significant ranging from 0.704 to 0.970 . The construct reliability was tested using composite reliability measures that assess the extent to which items in the construct measure the latent concept. Convergent validity of the CFA results should be supported by composite reliability (CR) and the average variance extracted (AVE) [119]. Hair et al. [119] proposed that the estimates of $\mathrm{CR}$ and $\mathrm{AVE}$, which measures the amount of variance explained by the given construct, should be higher than 0.700 and 0.500 , respectively. As presented in Table 3, the CR and AVE values ranged from 0.812 to 0.946 and 0.591 to 0.856 , respectively, surpassing the respective recommended levels of 0.700 and 0.500 . 
Table 3. Reliability and validity of the constructs.

\begin{tabular}{|c|c|c|c|c|c|}
\hline Construct & $\begin{array}{l}\text { Question } \\
\text { Item }\end{array}$ & Cronbach's $\alpha$ & $\begin{array}{c}\text { Standardized } \\
\text { Factor Loading }\end{array}$ & $\begin{array}{l}\text { Composite } \\
\text { Reliability }\end{array}$ & $\begin{array}{l}\text { Average } \\
\text { Variance } \\
\text { Extracted }\end{array}$ \\
\hline \multirow{3}{*}{$\begin{array}{l}\text { Attitude towards } \\
\text { purchasing green } \\
\text { products (ATT) }\end{array}$} & ATT1 & \multirow{3}{*}{0.858} & $0.891^{\mathrm{a}}$ & \multirow{3}{*}{0.873} & \multirow{3}{*}{0.680} \\
\hline & ATT2 & & $0.720 * * *$ & & \\
\hline & ATT3 & & $0.854^{* * *}$ & & \\
\hline \multirow{3}{*}{ Subjective norm (SN) } & SN1 & \multirow{3}{*}{0.808} & $0.705^{\mathrm{a}}$ & \multirow{3}{*}{0.812} & \multirow{3}{*}{0.593} \\
\hline & SN2 & & $0.760^{* * *}$ & & \\
\hline & SN3 & & $0.834^{* * *}$ & & \\
\hline \multirow{4}{*}{$\begin{array}{l}\text { Perceived behavioral } \\
\text { control (PBC) }\end{array}$} & PBC1 & \multirow{4}{*}{0.850} & $0.704^{\mathrm{a}}$ & \multirow{4}{*}{0.852} & \multirow{4}{*}{0.591} \\
\hline & $\mathrm{PBC} 2$ & & $0.768^{* * *}$ & & \\
\hline & PBC3 & & $0.830 * * *$ & & \\
\hline & $\mathrm{PBC} 4$ & & $0.813^{* * *}$ & & \\
\hline \multirow{4}{*}{$\begin{array}{l}\text { Environmental } \\
\text { concern (EC) }\end{array}$} & EC1 & \multirow{4}{*}{0.892} & $0.826^{\mathrm{a}}$ & \multirow{4}{*}{0.893} & \multirow{4}{*}{0.735} \\
\hline & EC2 & & $0.860^{* * *}$ & & \\
\hline & EC3 & & $0.885^{* * *}$ & & \\
\hline & $\mathrm{EC} 4$ & & $0.856^{* * *}$ & & \\
\hline \multirow{3}{*}{$\begin{array}{l}\text { Environmental } \\
\text { knowledge (EK) }\end{array}$} & EK1 & \multirow{3}{*}{0.830} & $0.745^{\mathrm{a}}$ & \multirow{3}{*}{0.830} & \multirow{3}{*}{0.624} \\
\hline & EK2 & & $0.794^{* * *}$ & & \\
\hline & EK3 & & $0.823 * * *$ & & \\
\hline \multirow{3}{*}{$\begin{array}{l}\text { Purchase intention for } \\
\text { green products }(\mathrm{PI})\end{array}$} & PI1 & \multirow{3}{*}{0.943} & $0.854^{a}$ & \multirow{3}{*}{0.946} & \multirow{3}{*}{0.856} \\
\hline & PI2 & & $0.950 * * *$ & & \\
\hline & PI3 & & $0.970^{* * *}$ & & \\
\hline
\end{tabular}

Note: ${ }^{* * *} p<0.001,{ }^{\text {a }}$ Values were not calculated because loading was set to 1.000 to fix construct variance.

All CFA results indicated that the measurement model had acceptable convergent and discriminant validities, the hypothesized measurement model was reliable and considerable for examining the structural associations among the constructs. The recommended acceptance of a considerable fit for a model requires that the obtained fit-indices of goodness-of-fit statistic (GFI), the adjusted goodness-of-fit statistic (AGFI), relative fit index (RFI), and normed-fit index (NFI) should be greater than 0.900 [120]. For alternative indices, comparative fit index (CFI) should be greater than 0.950, root mean square error of approximation (RMSEA) should be less than 0.080, and root mean square residual (RMR) should be less than 0.050 [121]. As shown in Table 4, the CFA results showed that the measurement model fit indices were as follows: the chi-square test result was 261.507 with 68 degrees of freedom (df), $p<0.001$, the ratio of the chi-square value to the $\mathrm{df}$ was 3.845 , and, according to the standard described by Marsh and Hocevar [122], we achieved a ratio of chi-square to the df ranging between 2 and 5. Furthermore, other fit index values for GFI, AGFI, RFI, NFI, CFI, RMSEA, and RMR were $0.939,0.918,0.969,0.963,0.971,0.068$, and 0.039 , respectively. The results exceeded their respective common acceptance levels. Therefore, the measurement model had a good fit with the data. In addition, Table 5 shows that the inter-correlations among measurement variables in the research model. All correlations were significant $(p<0.001)$.

Table 4. Measurement model fit indices.

\begin{tabular}{cccc}
\hline Fit Indices & Criteria & Indicators & Sources \\
\hline Chi-square & $p>0.050$ & $261.507(p<0.001)$ & {$[123-126]$} \\
Chi-square/df (degree of freedom) & $<5.000$ & $3.845(261.507 / 68)$ & \\
Goodness of Fit Index (GFI) & $>0.900$ & 0.939 & \\
Adjusted Goodness of Fit Index (AGFI) & $>0.900$ & 0.918 & \\
Relative Fit Index (RFI) & $>0.900$ & 0.969 & \\
Normed Fit Index (NFI) & $>0.900$ & 0.963 & \\
Comparative Fit Index (CFI) & $>0.950$ & 0.971 & \\
Root Mean Square Error of Approximation (RMSEA) & $<0.080$ & 0.068 & \\
Root Mean Square Residual (RMR) & $<0.050$ & 0.039 & \\
\hline
\end{tabular}


Table 5. Inter-correlations among model variables.

\begin{tabular}{|c|c|c|c|c|c|c|c|c|c|c|c|c|c|c|c|c|c|c|c|c|}
\hline & ATT1 & ATT2 & ATT3 & SN1 & SN2 & SN3 & PBC1 & PBC2 & PBC3 & PBC4 & EC1 & EC2 & EC3 & EC4 & EK1 & EK2 & EK3 & PI1 & PI2 & PI3 \\
\hline ATT1 & 1.000 & $0.509 * * *$ & $0.457^{* * *}$ & $0.448 * * *$ & $0.405^{* * *}$ & $0.479 * * *$ & $0.302 * * *$ & $0.375^{* * *}$ & $0.443 * * *$ & $0.539 * * *$ & $0.474^{* * *}$ & $0.446^{* * *}$ & $0.453 * * *$ & $0.473^{* * *}$ & $0.475 * * *$ & $0.307^{* * * *}$ & $0.527 * * *$ & $0.443 * * *$ & $0.489 * * *$ & $0.559 * * *$ \\
\hline ATT2 & & 1.000 & $0.613^{* * *}$ & $0.535^{* * *}$ & $0.523 * * *$ & $0.497^{* * *}$ & $0.451^{* * *}$ & $0.522 * * *$ & $0.508^{* * *}$ & $0.486 * * *$ & $0.463^{* * *}$ & $0.490^{* * *}$ & $0.507^{* * *}$ & $0.487^{* * * *}$ & $0.544 * * *$ & $0.457^{* * *}$ & $0.449 * * *$ & $0.465^{* * *}$ & $0.442 * * *$ & $0.447^{* * *}$ \\
\hline ATT3 & & & 1.000 & $0.713^{* * *}$ & $0.407^{* * *}$ & $0.452^{* * *}$ & $0.305^{* * *}$ & $0.285^{* * *}$ & $0.416^{* * *}$ & $0.530 * * *$ & $0.460^{* * *}$ & $0.530^{* * *}$ & $0.410^{* * *}$ & $0.592^{* * * *}$ & $0.502^{* * *}$ & $0.396^{* * *}$ & $0.502^{* * *}$ & $0.342^{* * *}$ & $0.507^{* * *}$ & $0.581^{* * *}$ \\
\hline SN1 & & & & 1.000 & $0.454^{* * *}$ & $0.458^{* * *}$ & $0.573^{* * *}$ & $0.385^{* * *}$ & $0.590 * * *$ & $0.579 * * *$ & $0.448^{* * *}$ & $0.452^{* * *}$ & $0.395^{* * *}$ & $0.381^{* * *}$ & $0.389 * * *$ & $0.415^{* * *}$ & $0.327^{* * *}$ & $0.435^{* * *}$ & $0.389 * * *$ & $0.402^{* * *}$ \\
\hline SN2 & & & & & 1.000 & $0.452 * * *$ & $0.592 * * *$ & $0.610^{* * *}$ & $0.566 * * *$ & $0.477^{* * *}$ & $0.440^{* * *}$ & $0.409^{* * *}$ & $0.412^{* * *}$ & $0.417^{* * *}$ & $0.554 * * *$ & $0.640^{* * *}$ & $0.456^{* * *}$ & $0.464^{* * *}$ & $0.561^{* * *}$ & $0.467^{* * *}$ \\
\hline SN3 & & & & & 1.000 & 1.000 & $0.751^{* * *}$ & 0.435 *** & $0.529 * * *$ & $0.584 * * *$ & $0.428 * * *$ & $0.496^{\text {**** }}$ & $0.508 * * *$ & $0.455 * * *$ & $0.464^{* * *}$ & $0.370^{* * *}$ & $0.444^{* * *}$ & $0.537^{* * *}$ & $0.579 * * *$ & 0.465 *** \\
\hline PBC1 & & & & & & & 1.000 & $0.714^{* * *}$ & $0.449^{* * *}$ & $0.510^{* * *}$ & $0.413^{* * *}$ & $0.370^{* * *}$ & $0.427^{* * *}$ & $0.359 * * *$ & $0.481^{* * *}$ & $0.484^{* * *}$ & $0.302^{* * *}$ & $0.395^{* * *}$ & $0.489^{* * *}$ & $0.548^{* * *}$ \\
\hline PBC2 & & & & & & & & 1.000 & $0.605^{* * *}$ & $0.511^{* * *}$ & $0.402 * * *$ & 0.302 *** & $0.428 * * *$ & $0.428 * * *$ & $0.473 * * *$ & $0.510^{* * * *}$ & $0.311^{* * *}$ & $0.431^{* * *}$ & $0.581^{* * *}$ & $0.441^{* * *}$ \\
\hline РВС3 & & & & & & & & & 1.000 & $0.608^{* * *}$ & $0.550^{* * *}$ & $0.449^{* * *}$ & $0.597^{* * *}$ & $0.404^{* * *}$ & $0.441^{* * *}$ & $0.343^{* * *}$ & $0.437^{* * *}$ & $0.486^{* * *}$ & $0.531^{* * *}$ & $0.480^{* * *}$ \\
\hline PBC4 & & & & & & & & & & 1.000 & $0.405^{* * *}$ & $0.511^{* * *}$ & $0.484^{* * *}$ & $0.499^{* * *}$ & $0.377^{* * *}$ & $0.369^{* * *}$ & $0.596^{* * *}$ & $0.504^{* * *}$ & $0.559 * * *$ & 0.430 *** \\
\hline EC1 & & & & & & & & & & & 1.000 & $0.692^{* * *}$ & $0.755^{* * *}$ & $0.544^{* * *}$ & $0.512^{* * *}$ & $0.477^{* * *}$ & $0.499^{* * *}$ & $0.500^{* * *}$ & $0.513^{* * *}$ & $0.585^{* * *}$ \\
\hline EC2 & & & & & & & & & & & & 1.000 & $0.601^{* * * *}$ & $0.548 * * *$ & $0.483^{* * *}$ & $0.375^{* * *}$ & $0.523^{* * *}$ & $0.517^{* * *}$ & $0.372 * * *$ & $0.536^{* * *}$ \\
\hline EC3 & & & & & & & & & & & & & 1.000 & $0.524^{* * *}$ & $0.581 * * *$ & $0.465^{* * *}$ & $0.515^{* * *}$ & $0.487 * * *$ & $0.482 * * *$ & $0.495^{* * *}$ \\
\hline EC4 & & & & & & & & & & & & & & 1.000 & $0.503^{* * *}$ & $0.351^{* * *}$ & $0.463^{* * *}$ & $0.475^{* * *}$ & $0.536^{* * *}$ & $0.452^{* * *}$ \\
\hline EK1 & & & & & & & & & & & & & & & 1.000 & 0.523 **** & $0.431 * * *$ & $0.362 * * *$ & $0.524 * * *$ & $0.469^{* * *}$ \\
\hline EK2 & & & & & & & & & & & & & & & & 1.000 & $0.538^{* * *}$ & $0.392 * * *$ & $0.532^{* * *}$ & $0.406^{* * *}$ \\
\hline EK3 & & & & & & & & & & & & & & & & & 1.000 & $0.537^{* * *}$ & $0.496^{* * *}$ & $0.520 * * *$ \\
\hline PI1 & & & & & & & & & & & & & & & & & & 1.000 & $0.769^{* * *}$ & 0.530 *** \\
\hline PI2 & & & & & & & & & & & & & & & & & & & 1.000 & $0.712^{* * *}$ \\
\hline PI3 & & & & & & & & & & & & & & & & & & & & 1.000 \\
\hline
\end{tabular}




\subsection{Testing of the Structural Equation Model}

SEM was conducted by AMOS 19.0 using a maximum likelihood parameter that evaluated the hypothesized conceptual model of this study (Figure 2). As shown in Table 6, significant and satisfactory goodness-of-fit indices were obtained; $\chi^{2}=320.991(p<0.001), \mathrm{df}=71, \chi^{2} / \mathrm{df}=4.521$, $\mathrm{GFI}=0.949, \mathrm{AGFI}=0.926, \mathrm{RFI}=0.978, \mathrm{NFI}=0.976, \mathrm{CFI}=0.958, \mathrm{RMSEA}=0.065$, and $\mathrm{RMR}=0.027$. All these indices were higher than the suggested goodness-of-fit values $[127,128]$ for the proposed structural model.

Table 7 shows that the results of the structural model, and the standardized path coefficient indicated positive effects among the constructs in the structural model. In total, nine out of eleven hypotheses were supported. The positive relationship between attitude towards purchasing green products and purchase intention for green products $(\mathrm{H} 1: \beta 1=0.562, \mathrm{t}=8.512, p<0.001)$ indicated that $\mathrm{H} 1$ was supported. According to $\mathrm{H} 2$, the positive estimate of coefficients between subjective norm and purchase intention for green products had significant positive effects $(\mathrm{H} 2: \beta 2=0.307, \mathrm{t}=5.012$, $p<0.01)$. Thus, $\mathrm{H} 2$ was supported. The impact of perceived behavioral control $(\mathrm{H} 3: \beta 3=0.405$, $t=6.512, p<0.001$ ) had significant positive effects on purchase intention for green products, supporting H3. Environmental concern had significant positive effect on purchase intention for green products (H4: $\beta 4=0.461, t=6.770, p<0.001$ ), attitude towards purchasing green products ( $\mathrm{H} 5: \quad \beta 5=0.342$, $\mathrm{t}=6.322, p<0.01)$ and perceived behavioral control (H7: $\beta 7=0.413, \mathrm{t}=8.921, p<0.001)$, but not on subjective norm (H6: $\beta 6=0.109, \mathrm{t}=1.498)$. Thus, H4, H5 and H7 were supported, while H6 was not supported. Finally, environmental knowledge showed significant positive influences on attitude towards purchasing green products (H9: $\beta 9=0.350, \mathrm{t}=4.977, p<0.01)$, subjective norm (H10: $\beta 10=0.245, t=3.478, p<0.05$ ) as well as perceived behavioral control (H11: $\beta 11=0.347$, $\mathrm{t}=6.458, p<0.01$ ), thus supporting H9, H10 and H11. However, environmental knowledge showed no significant influences on purchase intention for green products (H8: $\beta 8=0.045, t=0.827)$; hence, H8 was not supported. However, it had indirect effects through attitude towards purchasing green products, subjective norm and perceived behavioral control.

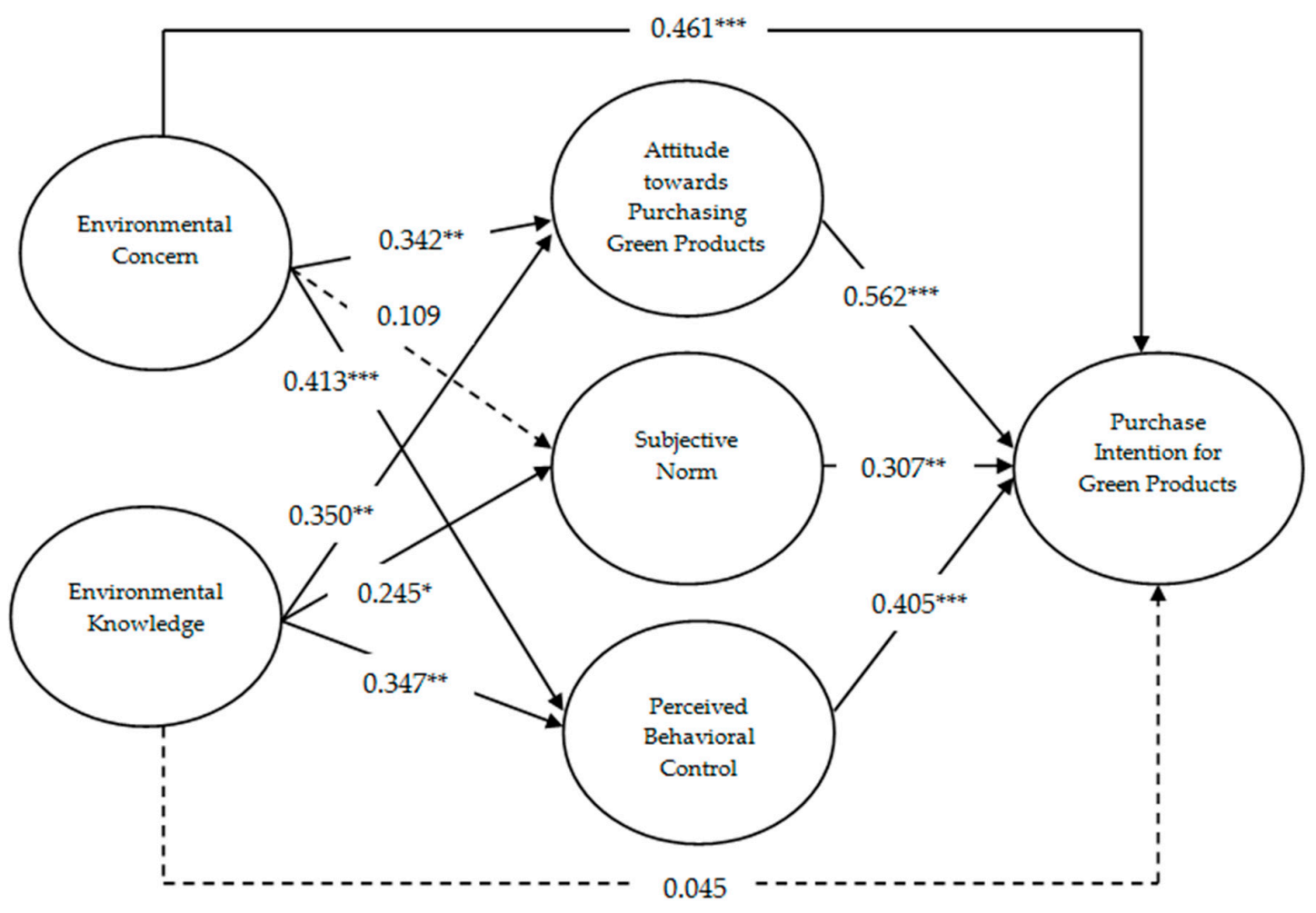

Figure 2. The results of the research model $\left({ }^{*} p<0.05 ;{ }^{* *} p<0.01 ;{ }^{* *} p<0.001\right)$. 
Table 6. Goodness-of-fit indices of the research model.

\begin{tabular}{cccc}
\hline Fit Indices & Criteria & Indicators & Sources \\
\hline Chi-square & $p>0.050$ & $320.991(p<0.001)$ & {$[124-126]$} \\
Chi-square/df (degree of freedom) & $<5.000$ & $4.521(320.991 / 71)$ & \\
Goodness of Fit Index (GFI) & $>0.900$ & 0.949 & \\
Adjusted Goodness of Fit Index (AGFI) & $>0.900$ & 0.926 \\
Relative Fit Index (RFI) & $>0.900$ & 0.978 \\
Normed Fit Index (NFI) & $>0.900$ & 0.976 \\
Comparative Fit Index (CFI) & $>0.950$ & 0.958 \\
Root Mean Square Error of Approximation (RMSEA) & $<0.080$ & 0.065 \\
Root Mean Square Residual (RMR) & $<0.050$ & 0.027 \\
\hline
\end{tabular}

Table 7. Hypotheses results for the structural model.

\begin{tabular}{clccc}
\hline Hypothesis & \multicolumn{1}{c}{ Path Correlation } & $\begin{array}{c}\text { Standardized Path } \\
\text { Coefficient }\end{array}$ & t-Value & Results \\
\hline H1 & $\begin{array}{l}\text { Attitude towards purchasing green products } \\
\rightarrow \text { Purchase intention for green products }\end{array}$ & $0.562^{* * *}$ & 8.512 & Supported \\
\hline H2 & $\begin{array}{l}\text { Subjective norm } \rightarrow \text { Purchase intention for } \\
\text { green products }\end{array}$ & $0.307^{* *}$ & 5.012 & Supported \\
\hline H3 & $\begin{array}{l}\text { Perceived behavioral control } \rightarrow \text { Purchase } \\
\text { intention for green products }\end{array}$ & $0.405^{* * *}$ & 6.512 & Supported \\
\hline H4 & $\begin{array}{l}\text { Environmental concern } \rightarrow \text { Purchase intention } \\
\text { for green products }\end{array}$ & $0.461^{* * *}$ & 6.770 & Supported \\
\hline H5 & $\begin{array}{l}\text { Environmental concern } \rightarrow \text { Attitude towards } \\
\text { purchasing green products }\end{array}$ & $0.342^{* *}$ & 6.322 & Supported \\
\hline H6 & Environmental concern $\rightarrow$ Subjective norm & 0.109 & 1.498 & Not supported \\
\hline H7 & $\begin{array}{l}\text { Environmental concern } \rightarrow \text { Perceived } \\
\text { behavioral control }\end{array}$ & $0.413^{* * *}$ & 8.921 & Supported \\
\hline H8 & $\begin{array}{l}\text { Environmental knowledge } \rightarrow \text { Purchase } \\
\text { intention for green products }\end{array}$ & 0.045 & 0.827 & Not supported \\
\hline H9 & $\begin{array}{l}\text { Environmental knowledge } \rightarrow \text { Attitude towards } \\
\text { purchasing green products }\end{array}$ & $0.350^{* *}$ & 4.977 & Supported \\
\hline H10 & Environmental knowledge $\rightarrow$ Subjective norm & $0.245^{*}$ & 3.478 & Supported \\
\hline H11 & $\begin{array}{l}\text { Environmental knowledge } \rightarrow \text { Perceived } \\
\text { behavioral control }\end{array}$ & $0.347^{* *}$ & 6.458 & Supported \\
\hline
\end{tabular}

Note: ${ }^{*} p<0.05 ;{ }^{* *} p<0.01 ;{ }^{* * *} p<0.001$.

\section{Discussion and Conclusions}

This study examined the extended framework of the TPB model, in which environmental concern and knowledge are added as antecedents of attitude towards purchasing green products, subjective norm and perceived behavioral control. The purpose was to investigate Thai consumers' aged over 18 years and those with a minimum high school education level on the purchase intention of green products. The result suggested that consumers' intention for this group to buy green products can be predicted by attitude, subjective norm; perceive behavioral control, environmental concern as well as environmental knowledge.

Attitude, social norms, and perceived behavioral control were found to have significant positive effects on purchase intention of green products. Attitude had the most significant influence on consumer's purchase intention, which shows that attitude was the strongest predictor of purchase intention for green products followed by perceived behavioral control and lastly subjective norm. The overall results confirmed that the TPB model and its measures were suitable for the studied group. Ajzen [68] observed that the more the positive attitude consumers have towards purchase behavior, the stronger the consumer's intentions to perform a behavior under their control. According to Tanner and 
Kast [129], the positive attitude of consumers towards environmental protection strongly facilitates purchasing green products. The empirical finding reported that subjective norms have lower influence on purchase intention for green products when compared to attitude and perceived behavioral control of the TPB model. The result of subjective norms indicate that friends/family members' influence resulted to a little thrust concerning the reasons to buy green products for consumers [14]. Perceived behavioral control has a direct influence on intention behavior according to the TPB model [68]. Therefore, the concept of perceived effectiveness of an individual's actions and their applications to products were considered effective in promoting favorable attitudes and sustainable consumption behaviors, resulting in being a major driving force in the competitive market. This relationship has a great influence in green marketing because perceived behavioral control has been considered a good indication of the individuals' intentions to purchase green products $[2,78,130]$.

Environmental concern was found to be significant and positive for attitude, perceived behavioral control and purchase intention for green products, which is supported by the findings of Chen and Tung [73], and Paul et al. [2]. In addition, this study suggests that environmental concern does not influence subjective norm among the studied group in Thailand.

Environmental knowledge was found to have significant positive influence for attitude, subjective norm, and perceived behavioral control for green products. Consumers will have a positive attitude towards purchasing green products if they have a high level of environmental knowledge; therefore, environmental knowledge has a significant role in environmental behavior. Kumar [22] showed that environmental knowledge has a significant positive relationship with attitude towards green products. In another aspect, the environmental knowledge failed to provide any positive thrust concerning the reason of purchase intention for green products, just as shown by Ahmad and Thyagaraj [131], and Chekima [132]. However, indirect effects were observed.

Our findings highlight several implications that may help in developing sound strategies for green products and their purchase intentions. Attitude towards purchasing green products, subjective norm and perceived behavioral control had high significant effect on the purchase intention with attitude having a strongest influence, followed by perceived behavioral control and lastly subjective norm. With attitude exerting a stronger influence than the subjective norm, marketers should try to attract the attention of Thai consumers towards green products using infomercials and promotions as this could help in influencing the consumers to purchase green products. Environmental knowledge had no significant effect on purchase intention for green products; however, it showed indirect effects through three TPB variables. For example, taking attitude towards purchasing green products as a mediator to purchase intention, Thai consumers who are knowledgeable about the environment and have positive attitudes make favorable adjustments towards purchase intention for green products. Environmental concern is among the strongest influences on the purchase intention for green products, suggesting that the government, private sector, entrepreneur, and marketers should develop public interventions showcasing how consumption of green products by the environmentally concerned could help in reducing adverse impacts on the environment. This could help increase the consumers' purchase intention for green products and also impact positively the environment within Thailand.

\section{Limitations and Future Directions}

The limitations and future directions of this study can be summarized in three points. First, the study considers green products in general instead of specific green products, so the findings could be different for different products. Future research should test the proposed model for various specific green products, such as organic products, recycled products, green toys, eco-car, green certified products, green restaurant, green hotels and so on. Second, the longitudinal approach is suggested as part of the research methods for further research to ascertain the change of attitude and purchase intention. Such an approach would be very useful in observing the reactions of consumers who intend to purchase more sustainable products towards green products and could also help us to understand 
how the behavioral intentions and attitudes are developed and influenced [133]. Finally, future studies may include samples from a diverse demographic population for more informed findings.

Acknowledgments: We would like to thank the survey respondents for taking their time to answer the questionnaire and the reviewers of this paper for their valuable comments.

Author Contributions: Kamonthip Maichum and Ke-Chung Peng were responsible for the concept, research design, data collection, statistical analysis, and writing of the manuscript. Surakiat Parichatnon distributed the questionnaire and conducted the analyses.

Conflicts of Interest: The authors declare no conflict of interest.

\section{References}

1. Bonini, S.M.; Oppenheim, J.M. Cultivating the green consumer. Stanf. Soc. Innov. Rev. 2008, 6, 56-61.

2. Paul, J.; Modi, A.; Patel, J. Predicting green product consumption using theory of planned behavior and reasoned action. J. Retail. Consum. Serv. 2016, 29, 123-134. [CrossRef]

3. Azeiteiro, U.M.; Alves, F.; Pinto de Moura, A.; Pardal, M.Â.; Pita, C.; Chuenpagdee, R.; Pierce, G.J. Participatory issues in fisheries governance in europe. Manag. Environ. Qual. Int. J. 2012, 23, 347-361.

4. Maignan, I.; Ferrell, O. Corporate social responsibility and marketing: An integrative framework. J. Acad. Mark. Sci. 2004, 32, 3-19. [CrossRef]

5. Kärnä, J.; Hansen, E.; Juslin, H. Social responsibility in environmental marketing planning. Eur. J. Mark. 2003, 37, 848-871. [CrossRef]

6. Banerjee, S.B.; Iyer, E.S.; Kashyap, R.K. Corporate environmentalism: Antecedents and influence of industry type. J. Mark. 2003, 67, 106-122. [CrossRef]

7. Yadav, R.; Pathak, G.S. Young consumers' intention towards buying green products in a developing nation: Extending the theory of planned behavior. J. Clean. Prod. 2016, 135, 732-739. [CrossRef]

8. Haytko, D.L.; Matulich, E. Green advertising and environmentally responsible consumer behaviors: Linkages examined. J. Manag. Mark. Res. 2008, 1, 2-11.

9. Ritter, Á.M.; Borchardt, M.; Vaccaro, G.L.; Pereira, G.M.; Almeida, F. Motivations for promoting the consumption of green products in an emerging country: Exploring attitudes of brazilian consumers. J. Clean. Prod. 2015, 106, 507-520. [CrossRef]

10. Mont, O.; Plepys, A. Sustainable consumption progress: Should we be proud or alarmed? J. Clean. Prod. 2008, 16, 531-537. [CrossRef]

11. Lijuan, L. Enhancing sustainable development through developing green food: China's option. In Sub-Regional Workshop; Dfid Ii Project, Ed.; United Nations in Bangkok: BKK, Thailand, 2003.

12. Calkins, M. Materials for Sustainable Sites: A Complete Guide to the Evaluation, Selection, and Use of Sustainable Construction Materials; John Wiley \& Sons: New York, NY, USA, 2008.

13. Ottman, J. Sometimes consumers will pay more to go green. Mark. News 1992, 26, 16.

14. Chan, R.Y.K.; Lau, L.B.Y. Explaining green purchasing behavior: A cross-cultural study on american and chinese consumers. J. Int. Consum. Mark. 2002, 14, 9-40. [CrossRef]

15. Barber, N.A.; Bishop, M.; Gruen, T. Who pays more (or less) for pro-environmental consumer goods? Using the auction method to assess actual willingness-to-pay. J. Environ. Psychol. 2014, 40, 218-227. [CrossRef]

16. Matthes, J.; Wonneberger, A.; Schmuck, D. Consumers' green involvement and the persuasive effects of emotional versus functional ads. J. Bus. Res. 2014, 67, 1885-1893. [CrossRef]

17. Onwezen, M.C.; Bartels, J.; Antonides, G. Environmentally friendly consumer choices: Cultural differences in the self-regulatory function of anticipated pride and guilt. J. Environ. Psychol. 2014, 40, 239-248. [CrossRef]

18. Kanchanapibul, M.; Lacka, E.; Wang, X.; Chan, H.K. An empirical investigation of green purchase behaviour among the young generation. J. Clean. Prod. 2014, 66, 528-536. [CrossRef]

19. Gracia, A.; de Magistris, T. Organic food product purchase behaviour: A pilot study for urban consumers in the south of italy. Span. J. Agric. Res. 2013, 5, 439-451. [CrossRef]

20. Zhao, H.-H.; Gao, Q.; Wu, Y.-P.; Wang, Y.; Zhu, X.-D. What affects green consumer behavior in China? A case study from qingdao. J. Clean. Prod. 2014, 63, 143-151. [CrossRef]

21. Biswas, A.; Roy, M. Green products: An exploratory study on the consumer behaviour in emerging economies of the east. J. Clean. Prod. 2015, 87, 463-468. [CrossRef] 
22. Kumar, B. Theory of Planned Behaviour Approach to Understand the Purchasing Behaviour for Environmentally Sustainable Products; Indian Institute of Management Ahmedabad, Research and Publication Department: Ahmedabad, India, 2012.

23. Chairy, C. Spirituality, self-transcendence, and green purchase intention in college students. J. Soc. Behav. Sci. 2012, 57, 243-246. [CrossRef]

24. Tan, B.-C. The roles of knowledge, threat, and pce on green purchase behaviour. Int. J. Bus. Manag. 2011, 6, 14-27. [CrossRef]

25. Nuttavuthisit, K.; Thøgersen, J. The importance of consumer trust for the emergence of a market for green products: The case of organic food. J. Bus. Ethics 2015. [CrossRef]

26. Vongmahadlek, J. An empirical study on organic product purchasing behavior: A case study of thailand. AU J. Manag. 2012, 10, 31-39.

27. Arttachariya, P. Environmentalism and green purchasing behavior: A study on graduate students in Bangkok, Thailand. BU Acad. Rev. 2012, 11, 1-11.

28. Ajzen, I.; Manstead, A.S. Changing health-related behaviors: An approach based on the theory of planned behavior. In The Scope of Social Psychology: Theory and Applications; Psychology Press: New York, NY, USA, 2007.

29. Fishbein, M.; Ajzen, I. Belief, Attitude, Intention and Behavior: An Introduction to Theory and Research; Addison-Wesley Publishing Company: Reading, MA, USA, 1975.

30. Vazifehdoust, H.; Taleghani, M.; Esmaeilpour, F.; Nazari, K.; Khadang, M. Purchasing green to become greener: Factors influence consumers' green purchasing behavior. Manag. Sci. Lett. 2013, 3, 2489-2500. [CrossRef]

31. Zakersalehi, M.; Zakersalehi, A. Consumers' attitude and purchasing intention toward green packaged foods: A malaysian perspective. In Proceedings of the 2012 International Conference on Economics, Marketing and Management, Hong Kong, China, 5-7 January 2012; Volume 28, pp. 1-5.

32. Gilg, A.; Barr, S.; Ford, N. Green consumption or sustainable lifestyles? Identifying the sustainable consumer. Futures 2005, 37, 481-504. [CrossRef]

33. Ajzen, I.; Fishbein, M. Attitude-behavior relations: A theoretical analysis and review of empirical research. Psychol. Bull. 1977, 84, 888-918. [CrossRef]

34. Weigel, R.H. Environmental attitudes and the prediction of behavior. In Environmental Psychology: Directions and Perspectives; Feimer, N.R., Geller, E.S., Eds.; Praeger: New York, NY, USA, 1983; pp. 257-287.

35. Ohtomo, S.; Hirose, Y. The dual-process of reactive and intentional decision-making involved in eco-friendly behavior. J. Environ. Psychol. 2007, 27, 117-125. [CrossRef]

36. Scott, L.; Vigar-Ellis, D. Consumer understanding, perceptions and behaviours with regard to environmentally friendly packaging in a developing nation. Int. J. Consum. Stud. 2014, 38, 642-649. [CrossRef]

37. Diamantopoulos, A.; Schlegelmilch, B.B.; Sinkovics, R.R.; Bohlen, G.M. Can socio-demographics still play a role in profiling green consumers? A review of the evidence and an empirical investigation. J. Bus. Res. 2003, 56, 465-480. [CrossRef]

38. Vega-Zamora, M.; Parras-Rosa, M.; Murgado-Armenteros, E.M.; Torres-Ruiz, F.J. A powerful word: The influence of the term 'organic' on perceptions and beliefs concerning food. Int. Food Agribus. Manag. Rev. 2013, 16, 51-76.

39. Arslan, T.; Yilmaz, V.; Aksoy, H. Structural equation model for environmentally conscious purchasing behavior. Int. J. Environ. Res. 2012, 6, 323-334.

40. Franzen, A.; Meyer, R. Environmental attitudes in cross-national perspective: A multilevel analysis of the issp 1993 and 2000. Eur. Sociol. Rev. 2010, 26, 219-234. [CrossRef]

41. Sidique, S.F.; Lupi, F.; Joshi, S.V. The effects of behavior and attitudes on drop-off recycling activities. Resour. Conserv. Recycl. 2010, 54,163-170. [CrossRef]

42. National Statistics Office (NSO). The 2015 Household Socio-Economic Survey Whole Kingdom; NSO: Bangkok, Thailand, 2016.

43. Teerachote, C.; Kessomboom, P.; Rattanasiri, A.; Koju, R. Improving health consciousness and life skills in young people through peer-leadership in thailand. Kathmandu Univ. Med. J. 2014, 11, 41-44. [CrossRef]

44. Srivastava, S.K. Green supply-chain management: A state-of-the-art literature review. Int. J. Manag. Rev. 2007, 9, 53-80. [CrossRef]

45. Soonthonsmai, V. Environmental or Green Marketing as Global Competitive Edge: Concept, Synthesis, and Implication. In Proceedings of the EABR (Business) and ETLC (Teaching) Conference, Venice, Italy, 4-7 June 2007. 
46. Azeiteiro, U.M.; Alves, F.; Pinto de Moura, A.; Pardal, M.Â.; Pinto de Moura, A.; Cunha, L.M.; Castro-Cunha, M.; Costa Lima, R. A comparative evaluation of women's perceptions and importance of sustainability in fish consumption: An exploratory study among light consumers with different education levels. Manag. Environ. Qual. Int. J. 2012, 23, 451-461.

47. Roman, T.; Bostan, I.; Manolică, A.; Mitrica, I. Profile of green consumers in romania in light of sustainability challenges and opportunities. Sustainability 2015, 7, 6394-6411. [CrossRef]

48. Chen, A.; Peng, N. Green hotel knowledge and tourists' staying behavior. Ann. Tour. Res. 2012, 39, $2211-2216$. [CrossRef]

49. Klopping, I.M.; McKinney, E. Extending the technology acceptance model and the task-technology fit model to consumer e-commerce. Inform. Technol. Learn. Perform. J. 2004, 22, 35.

50. Ajzen, I. From intentions to actions: A theory of planned behavior. In Action Control; Kuhl, J., Beckmann, J., Eds.; Springer: Berlin/Heidelberg, Germany, 1985; pp. 11-39.

51. Ajzen, I.; Madden, T.J. Prediction of goal-directed behavior: Attitudes, intentions, and perceived behavioral control. J. Exp. Soc. Psychol. 1986, 22, 453-474. [CrossRef]

52. Fielding, K.S.; McDonald, R.; Louis, W.R. Theory of planned behaviour, identity and intentions to engage in environmental activism. J. Environ. Psychol. 2008, 28, 318-326. [CrossRef]

53. Collins, S.E.; Carey, K.B. The theory of planned behavior as a model of heavy episodic drinking among college students. Psychol. Addict. Behav. 2007, 21, 498-507. [CrossRef] [PubMed]

54. Patch, C.S.; Tapsell, L.C.; Williams, P.G. Attitudes and intentions toward purchasing novel foods enriched with omega-3 fatty acids. J. Nutr. Educ. Behav. 2005, 37, 235-241. [CrossRef]

55. Liobikienè, G.; Mandravickaitè, J.; Bernatonienè, J. Theory of planned behavior approach to understand the green purchasing behavior in the EU: A cross-cultural study. Ecol. Econ. 2016, 125, 38-46. [CrossRef]

56. Ajzen, I. Perceived behavioral control, self-efficacy, locus of control, and the theory of planned behavior. J. Appl. Soc. Psychol. 2002, 32, 665-683. [CrossRef]

57. Han, H.; Hsu, L.-T.J.; Sheu, C. Application of the theory of planned behavior to green hotel choice: Testing the effect of environmental friendly activities. Tour. Manag. 2010, 31, 325-334. [CrossRef]

58. Rezai, G.; Teng, P.K.; Mohamed, Z.; Shamsudin, M.N. Consumers' awareness and consumption intention towards green foods. Afr. J. Bus. Manag. 2012, 6, 4496-4503.

59. Jones, P.; Comfort, D.; Hillier, D. Sustainability in the global shop window. Int. J. Retail Distrib. Manag. 2011, 39, 256-271. [CrossRef]

60. Sutton, P. A perspective on environmental sustainability. In Paper on the Victorian Commissioner for Environmental Sustainability; RSTI Publications, Inc.: Melbourne, Victoria, Australia, 2004; pp. 1-32.

61. Fazio, R.H. Attitudes as object-evaluation associations: Determinants, consequences, and correlates of attitude accessibility. Attitude Strength Anteced. Conseq. 1995, 4, 247-282.

62. Bonne, K.; Vermeir, I.; Bergeaud-Blackler, F.; Verbeke, W. Determinants of halal meat consumption in france. Br. Food J. 2007, 109, 367-386. [CrossRef]

63. Schiffman, L.G.; Kanuk, L.L. Purchasing Behavior; Pearson Prentice Hall: Upper Saddle River, NJ, USA, 2007.

64. Eagly, A.H.; Chaiken, S. Attitude strength, attitude structure, and resistance to change. Attitude Strength Anteced. Conseq. 1995, 4, 413-432.

65. Irland, L.C. Wood producers face green marketing era: Environmentally sound products. Wood Technol. 1993, 120, 34-36.

66. Tsen, C.-H.; Phang, G.; Hasan, H.; Buncha, M.R. Going green: A study of consumers' willingness to pay for green products in kota kinabalu. Int. J. Bus. Soc. 2006, 7, 40-54.

67. Mostafa, M.M. A hierarchical analysis of the green consciousness of the egyptian consumer. Psychol. Mark. 2007, 24, 445-473. [CrossRef]

68. Ajzen, I. Theories of cognitive self-regulation the theory of planned behavior. Organ. Behav. Hum. Decis. Process. 1991, 50, 179-211. [CrossRef]

69. Hee, S. Relationships among attitudes and subjective norm: Testing the theory of reasoned action cultures. Commun. Stud. 2000, 51, 162-175.

70. Zukin, S.; Maguire, J.S. Consumers and consumption. Annu. Rev. Sociol. 2004, 30, 173-197. [CrossRef]

71. Wiriyapinit, M. Is thai culture the right culture for knowledge management?: An exploratory case study research. Chulalongkorn Rev. 2007, 74, 80-90. 
72. Dean, M.; Raats, M.M.; Shepherd, R. The role of self-identity, past behavior, and their interaction in predicting intention to purchase fresh and processed organic food. J. Appl. Soc. Psychol. 2012, 42, 669-688. [CrossRef]

73. Chen, M.-F.; Tung, P.-J. Developing an extended theory of planned behavior model to predict consumers' intention to visit green hotels. Int. J. Hosp. Manag. 2014, 36, 221-230. [CrossRef]

74. Teng, Y.-M.; Wu, K.-S.; Liu, H.-H. Integrating altruism and the theory of planned behavior to predict patronage intention of a green hotel. J. Hosp. Tour. Res. 2013. [CrossRef]

75. Zhou, Y.; Thøgersen, J.; Ruan, Y.; Huang, G. The moderating role of human values planned behaviour: The case of chinese consumers' intention to buy organic food. J. Consum. Mark. 2013, 30, 335-344. [CrossRef]

76. Li, H.; Daugherty, T.; Biocca, F. Impact of 3-D advertising on product knowledge, brand attitude, and purchase intention: The mediating role of presence. J. Advert. 2002, 31, 43-57. [CrossRef]

77. Olsen, S.O. Antecedents of seafood consumption behavior: An overview. J. Aquat. Food Prod. Technol. 2004, 13, 79-91. [CrossRef]

78. Baker, E.W.; Al-Gahtani, S.S.; Hubona, G.S. The effects of gender and age on new technology implementation in a developing country: Testing the theory of planned behavior (TPB). Inform. Technol. People 2007, 20, 352-375. [CrossRef]

79. Taylor, S.; Todd, P. Decomposition and crossover effects in the theory of planned behavior: A study of consumer adoption intentions. Int. J. Res. Mark. 1995, 12, 137-155. [CrossRef]

80. Thøgersen, J. Consumer decision-making with regard to organic food products: Results from the condor project. In Proceedings of the Traditional Food Processing and Technological Innovation Conference, Faro, Portugal, 26 May 2006.

81. Tarkiainen, A.; Sundqvist, S. Subjective norms, attitudes and intentions of finnish consumers in buying organic food. Br. Food J. 2005, 107, 808-822. [CrossRef]

82. Moser, A.K. Thinking green, buying green? Drivers of pro-environmental purchasing behavior. J. Consum. Mark. 2015, 32, 167-175. [CrossRef]

83. Alibeli, M.A.; Johnson, C. Environmental concern: A cross national analysis. J. Int. Cross-Cult. Stud. 2009, 3, 1-10.

84. Aman, A.L.; Harun, A.; Hussein, Z. The influence of environmental knowledge and concern on green purchase intention the role of attitude as a mediating variable. Br. J. Arts Soc. Sci. 2012, 7, 145-167.

85. Hutchins, R.K.; Greenhalgh, L. Organic confusion: Sustaining competitive advantage. Br. Food J. 1997, 99, 336-338. [CrossRef]

86. Davies, A.; Titterington, A.J.; Cochrane, C. Who buys organic food? A profile of the purchasers of organic food in northern ireland. Br. Food J. 1995, 97, 17-23. [CrossRef]

87. Albayrak, T.; Aksoy, S.; Caber, M. The effect of environmental concern and scepticism on green purchase behaviour. Mark. Intell. Plan. 2013, 31, 27-39. [CrossRef]

88. Irawan, R.; Darmayanti, D. The influence factors of green purchasing behavior: A study of university students in Jakarta. In Proceedings of the 6th Asian Business Research Conference, Bangkok, Thailand, 8-10 April 2012; pp. 1-11.

89. Hanson, C.B. Environmental concern, attitude toward green corporate practices, and green consumer behavior in the United States and Canada. ASBBS E J. 2013, 9, 62.

90. Bamberg, S. How does environmental concern influence specific environmentally related behaviors? A new answer to an old question. J. Environ. Psychol. 2003, 23, 21-32. [CrossRef]

91. Hartmann, P.; Apaolaza-Ibáñez, V. Consumer attitude and purchase intention toward green energy brands: The roles of psychological benefits and environmental concern. J. Bus. Res. 2012, 65, 1254-1263. [CrossRef]

92. Taufique, K.M.R.; Siwar, C.; Chamhuri, N.; Sarah, F.H. Integrating general environmental knowledge and eco-label knowledge in understanding ecologically conscious consumer behavior. Procedia Econ. Financ. 2016, 37, 39-45. [CrossRef]

93. Fryxell, G.E.; Lo, C.W. The influence of environmental knowledge and values on managerial behaviours on behalf of the environment: An empirical examination of managers in china. J. Bus. Ethics 2003, 46, 45-69. [CrossRef]

94. Hill, H.; Lynchehaun, F. Organic milk: Attitudes and consumption patterns. Br. Food J. 2002, 104, 526-542. [CrossRef]

95. Lee, N.; Choi, Y.J.; Youn, C.; Lee, Y. Does green fashion retailing make consumers more eco-friendly? The influence of green fashion products and campaigns on green consciousness and behavior. Cloth. Text. Res. J. 2012, 30, 67-82. [CrossRef] 
96. Mahesh, N.; Ganapathi, R. Influence of consumer's socio-economic characteristics and attitude on purchase intention of green products. Int. J. Bus. Manag. 2012, 4, 33-37.

97. Wang, P.; Liu, Q.; Qi, Y. Factors influencing sustainable consumption behaviors: A survey of the rural residents in China. J. Clean. Prod. 2014, 63, 152-165. [CrossRef]

98. Vicente-Molina, M.A.; Fernández-Sáinz, A.; Izagirre-Olaizola, J. Environmental knowledge and other variables affecting pro-environmental behaviour: Comparison of university students from emerging and advanced countries. J. Clean. Prod. 2013, 61, 130-138. [CrossRef]

99. Mostafa, M.M. Shades of green: A psychographic segmentation of the green consumer in kuwait using self-organizing maps. Expert Syst. Appl. 2009, 36, 11030-11038. [CrossRef]

100. Bradley, J.C.; Waliczek, T.M.; Zajicek, J.M. Relationship between environmental knowledge and environmental attitude of high school students. J. Environ. Educ. 2010, 30, 17-21. [CrossRef]

101. Moorman, C.; Diehl, K.; Brinberg, D.; Kidwell, B. Subjective knowledge, search locations, and consumer choice. J. Consum. Res. 2004, 31, 673-680. [CrossRef]

102. Yang, Z.J.; Kahlor, L. What, me worry? The role of affect in information seeking and avoidance. Sci. Commun. 2013, 35, 189-212. [CrossRef]

103. Kim, Y.; Yun, S.; Lee, J. Can companies induce sustainable consumption? The impact of knowledge and social embeddedness on airline sustainability programs in the us. Sustainability 2014, 6, 3338-3356. [CrossRef]

104. Chan, R.Y. Determinants of Chinese consumers' green purchase behavior. Psychol. Mark. 2001, 18, $389-413$. [CrossRef]

105. Hedlund, T. The impact of values, environmental concern, and willingness to accept economic sacrifices to protect the environment on tourists' intentions to buy ecologically sustainable tourism alternatives. Tour. Hosp. Res. 2011, 11, 278-288. [CrossRef]

106. Han, H.; Kim, Y. An investigation of green hotel customers' decision formation: Developing an extended model of the theory of planned behavior. Int. J. Hosp. Manag. 2010, 29, 659-668. [CrossRef]

107. Alwitt, L.F.; Pitts, R.E. Predicting purchase intentions for an environmentally sensitive product. J. Consum. Psychol. 1996, 5, 49-64. [CrossRef]

108. Szolnoki, G.; Hoffmann, D. Online, face-to-face and telephone surveys-Comparing different sampling methods in wine consumer research. Wine Econ. Policy 2013, 2, 57-66. [CrossRef]

109. Kinnear, T.; Taylor, J. Marketing Research: An Applied Research; McGraw Hill: New York, NY, USA, 1996.

110. Nunnally, J.C.; Bernstein, I. Elements of statistical description and estimation. In Psychometric Theory, 3rd ed.; Nunnally, J.C., Bernstein, I.H., Eds.; McGraw Hill: New York, NY, USA, 1994.

111. Charter, M. Greener Marketing: A Global Perspective on Greening Marketing Practice; Greenleaf Publishing: Sheffield, UK, 1999.

112. Mostafa, M.M. Antecedents of Egyptian consumers' green purchase intentions: A hierarchical multivariate regression model. J. Int. Consum. Mark. 2006, 19, 97-126. [CrossRef]

113. Armitage, C.J.; Conner, M. Efficacy of the theory of planned behaviour: A meta-analytic review. Br. J. Soc. Psychol. 2001, 40, 471-499. [CrossRef] [PubMed]

114. Kilbourne, W.; Pickett, G. How materialism affects environmental beliefs, concern, and environmentally responsible behavior. J. Bus. Res. 2008, 61, 885-893. [CrossRef]

115. Chang, H.H.; Chen, S.W. The impact of online store environment cues on purchase intention: Trust and perceived risk as a mediator. Online Inform. Rev. 2008, 32, 818-841. [CrossRef]

116. Malhotra, N.K. Questionnaire design and scale development. In The Handbook of Marketing Research: Uses, Misuses, and Future Advances; SAGE Publications, Inc.: Thousand Oaks, CA, USA, 2006; pp. 176-202.

117. Chen, Y.-S.; Lin, C.-Y.; Weng, C.-S. The influence of environmental friendliness on green trust: The mediation effects of green satisfaction and green perceived quality. Sustainability 2015, 7, 10135-10152. [CrossRef]

118. Tang, M.-L. Evaluating green hotels in taiwan from the consumer's perspective. Int. J. Manag. Res. Bus. Strategy 2015, 4, 1-15.

119. Hair, J.; Anderson, R.; Tatham, R.; Black, W. Conjoint analysis. In Multivariate Data Analysis; Pearson Education: Upper Saddle River, NJ, USA, 1998; pp. 387-441.

120. Steiger, J.H. Understanding the limitations of global fit assessment in structural equation modeling. Personal. Individ. Differ. 2007, 42, 893-898. [CrossRef]

121. Tabachnick, B.G.; Fidell, L.S.; Osterlind, S.J. Using Multivariate Statistics; Pearson Education: Upper Saddle River, NJ, USA, 2001. 
122. Marsh, H.W.; Hocevar, D. Application of confirmatory factor analysis to the study of self-concept: First-and higher order factor models and their invariance across groups. Psychol. Bull. 1985, 97, 562-582. [CrossRef]

123. Anderson, J.C.; Gerbing, D.W. Structural equation modeling in practice: A review and recommended two-step approach. Psychol. Bull. 1988, 103, 411-423. [CrossRef]

124. Hair, J.F.; Sarstedt, M.; Ringle, C.M.; Mena, J.A. An assessment of the use of partial least squares structural equation modeling in marketing research. J. Acad. Mark. Sci. 2012, 40, 414-433. [CrossRef]

125. Hoe, S.L. Issues and procedures in adopting structural equation modeling technique. J. Appl. Quant. Methods 2008, 3, 76-83.

126. Bentler, P.M.; Bonett, D.G. Significance tests and goodness of fit in the analysis of covariance structures. Psychol. Bull. 1980, 88, 588-606. [CrossRef]

127. Bollen, K.A. A new incremental fit index for general structural equation models. Sociol. Methods Res. 1989, 17, 303-316. [CrossRef]

128. Browne, M.W.; Cudeck, R. Alternative ways of assessing model fit. Sociol. Methods Res. 1992, 21, $230-258$. [CrossRef]

129. Tanner, C.; Kast, S.W. Promoting sustainable consumption: Determinants of green purchases by swiss consumers. Psychol. Mark. 2003, 20, 883-902. [CrossRef]

130. Cheng, S.; Lam, T.; Hsu, C.H. Negative word-of-mouth communication intention: An application of the theory of planned behavior. J. Hosp. Tour. Res. 2006, 30, 95-116. [CrossRef]

131. Ahmad, A.; Thyagaraj, K. Consumer's intention to purchase green brands: The roles of environmental concern, environmental knowledge and self expressive benefits. Curr. World Environ. 2015, 10, 879-889. [CrossRef]

132. Chekima, B. Consumer values and green products consumption in malaysia: A structural equation modelling approach. In Handbook of Research on Consumerism and Buying Behavior in Developing Nations; IGI Global: Hershey, PA, USA, 2016; pp. 383-408.

133. Pettigrew, A.M. Longitudinal field research on change: Theory and practice. Organ. Sci. 1990, 1, $267-292$. [CrossRef]

(C) 2016 by the authors; licensee MDPI, Basel, Switzerland. This article is an open access article distributed under the terms and conditions of the Creative Commons Attribution (CC-BY) license (http://creativecommons.org/licenses/by/4.0/). 